\title{
UJI EFEK ANTIPLASMODIUM EKSTRAK ETANOL RUMPUT TEKI (Cyperus rotundus L.) PADA MENCIT JANTAN
}

\author{
Jangga \\ Universitas Mega Rezky
}

Koresponden: jangga.angga@yahoo.co.id

\begin{abstract}
ABSTRAK
Penelitian ini bertujuan untuk menentukan konsentrasi ekstrak etanol Rumput teki yang dapat memberikan efek antiplasmodium terhadap mencit jantan. Jenis penelitian adalah penelitian eksperimental laboratorium yang menggunakan hewan uji mencit jantan sebanyak 12 ekor yang dimaksudkan untuk mengetahui efek antiplasmodium ekstrak etanol Rumput Teki. Pelaksanaan penelitian dilakukan di laboratorium Biofarmasi Fakultas Farmasi Universitas Indonesia Timur tanggal 27 Agustus sampai dengan 29 September 2017. Hasil penelitian ini menunjukkan bahwa ekstrak etanol Rumput Teki dengan konsentrasi $2 \%$ b/v, $4 \%$ b/v, dan $6 \%$ b/v dapat menghambat perkembangan parasitemia dalam sel darah merah mencit jantan yang terinfeksi Plasmodium berghei. Ekstrak etanol Rumput Teki dengan konsentrasi $6 \% \mathrm{~b} / \mathrm{v}$ menunjukkan penurunan persentase parasitemia lebih besar.
\end{abstract}

Kata Kunci : Antiplasmodium, Rumput Teki

\section{PENDAHULUAN}

Malaria adalah penyakit infeksi parasit utama di dunia yang mengenai hampir 170 juta orang tiap tahunnya. Penyakit ini juga berjangkit dihampir 103 negara, terutama Negara-negara didaerah tropis pada ketinggian antara 400-3000 m dari permukaan laut dengan kelembaban udara tidak kurang dari $60 \%$.

Di Indonesia, malaria tergolong penyakit menular yang paling besar. Penyakit ini berjangkit disemua pulau di Indonesia, mulai dari dataran rendah hingga dataran tinggi, baik di kota maupun di Desa (Anneahira, 2010)

Salah satu tanaman obat yang biasa digunakan sebagai obat tradisional adalah Rumput teki (Cyperus rotundus L.) dari suku Cyperaceae. Tanaman ini belum banyak digunakan oleh masyarakat serta zat-zat yang terkandung didalam tanaman ini juga belum seluruhnya diteliti, sehingga pemanfaatannya untuk penyembuhan penyakit masih terbatas.

Adapun kandungan kimia dari Rumput teki adalah alkaloid, glikosida jantung, flavonoid, dan minyak menguap. Khasiatnya yaitu sakit dada, sakit iga, sakit sewaktu haid, memar, gata-gatal kulit, bisul dan malaria.

\section{METODE}

Jenis,tempat dan waktu penelitian

Jenis penelitian yang digunakan adalah penelitian eksperimental laboratorium yang menggunakan hewan uji mencit jantan yang dimaksudkan untuk mengetahui efek antiplasmodium ekstrak etanol Rumput Teki yang dibuat ekstrak 
dengan konsentrasi $2 \% \mathrm{~b} / \mathrm{v}, 4 \% \mathrm{~b} / \mathrm{v}$, dan $6 \% \mathrm{~b} / \mathrm{v}$.

\section{Waktu dan Lokasi Penelitian}

Pelaksanaan penelitian dilakukan di laboratorium Biofarmasi Fakultas Farmasi Universitas Indonesia Timur pada tanggal 27 Agustus sampai dengan 29 September 2017.

\section{Prosedur penelitian}

Alat-alat yang digunakan adalah seperangkat alat maserasi, seperangkat alat bedah, seperangkat alat rotavapor, mikroskop, objek glass, dek glass, kertas saring, neraca analitik, timbangan O'hauss, spoit oral, gelas kimia, gelas ukur, kandang hewan uji. Sedangkan bahan yang digunakan adalah Rumput teki, etanol $70 \%$, Giemsa, Na. CMC 1\%, Minyak imersi, metanol, mencit, dan Plasmodium berghei.

\section{Cara kerja}

1. Pengambilan dan Pengolahan Sampel

Bahan penelitian berupa herba Rumput Teki diambil di Kota Makassar Sulawesi Selatan. Pengambilan tumbuhan ini dilakukan pada pagi hari sekitar pukul 10.00 WITA, dengan cara mengambil seluruh bagian tanaman kecuali akar kemudian dilakukan pencucian dengan air mengalir.

Seluruh bagian tanaman yang telah bersih dikeringkan dengan cara dianginkan-anginkan pada tempat yang tidak terpapar sinar matahari langsung kemudian dipotong-potong kecil, sampel siap untuk diekstraksi.

2. Ekstraksi Sampel

Simplisia Rumput Teki sebanyak 300 gram dimasukkan dalam Bejana Maserasi, ditambahkan etanol $70 \%$ hingga simplisia tersebut terendam, dibiarkan selama 5 hari dalam bejana tertutup dan terlindung dari cahaya sambil berulangulang diaduk. Setelah 5 hari simplisia disaring dan ampasnya direndam lagi dengan cairan penyari yang baru. Hal ini dilakukan sebanyak 3 kali. Hasil penyarian yang didapat kemudian dikumpulkan dan diuapkan dengan menggunakan rotavapor hingga diperoleh ekstrak etanol yang kental.

3. Pembuatan suspensi ekstrak etanol Rumput teki.

Ekstrak Rumput Teki yang digunakan dalam penelitian ini dibuat dengan konsentrasi $2 \%$ $\mathrm{b} / \mathrm{v}, 4 \% \mathrm{~b} / \mathrm{v}$ dan $6 \% \mathrm{~b} / \mathrm{v}$. Untuk membuat konsentrasi $2 \% \mathrm{~b} / \mathrm{v}$, ditimbang ekstrak etanol Rumput teki sebanyak 2 gram kemudian dimasukan dalam lumpang dan digerus sambil ditambahkan sedikit demi sedikit larutan $\mathrm{Na}$. CMC $1 \% \mathrm{~b} / \mathrm{v}$, setelah homogen dimasukkan ke dalam labu ukur $100 \mathrm{ml}$ dan dicukupkan volumenya dengan $\mathrm{Na}$. CMC $1 \%$ $\mathrm{b} / \mathrm{v}$ hingga $100 \mathrm{ml}$. Untuk suspensi ekstrak etanol konsentrasi $4 \% \mathrm{~b} / \mathrm{v}$ dan $6 \% \mathrm{~b} / \mathrm{v}$ dibuat dengan cara yang sama.

4. Pembuatan Larutan Koloidal Na. CMC $1 \%$ b/v

Ditimbang Na. CMC sebanyak 1 gram, kemudian di masukkan sedikit demi sedikit kedalam $50 \mathrm{ml}$ air suling yang telah di panaskan sambil di aduk cepat dengan batang pengaduk hingga terbentuk larutan homogen, dicukupkan volumenya hingga $100 \mathrm{ml}$. 
Jurnal Media Analis Kesehatan, Vol. 8, No.2, November 2017

http://journal.poltekkes-mks.ac.id/ojs2/index.php/mediaanalis

e-ISSN : 2621-9557

p-ISSN : 2087-1333

\begin{tabular}{l|l|l|l|l|l}
\hline \multirow{5}{*}{ Kontrol } & 1,65 & 8,12 & 19 & 38,8 & 43,7 \\
\hline \multicolumn{5}{l}{} \\
\multicolumn{5}{l|}{} \\
\hline
\end{tabular}

Sumber : Data Primer 2017

Hubungan log dosis dengan probit, maka berikut ini akan diuraikan perhitungan $\mathrm{SD}_{50}$ ekstrak etanol Rumput Teki

\begin{tabular}{llllll}
\hline $\mathbf{X}$ & $\mathbf{d}(\mathbf{m g})$ & $\mathbf{P ( \% )}$ & $\mathbf{Y}$ & $\mathbf{X}^{\mathbf{2}}$ & $\mathbf{X . Y}$ \\
\hline $\mathbf{0}$ & 2 & 23,47 & 4,266 & 0 & 0 \\
\hline $\mathbf{1}$ & 4 & 59,52 & 5,245 & 1 & 5,245 \\
\hline $\mathbf{2}$ & 6 & 77,69 & 5,761 & 4 & 11,522 \\
\hline$\sum=\mathbf{3}$ & & & $\sum_{15,272}=$ & $\sum$ \\
& & & 15 & $\sum=16,767$
\end{tabular}

Keterangan : Supresi dosis 50\% $\left(\mathrm{SD}_{50}\right)$

$$
\begin{aligned}
\mathrm{b} & =\frac{n\left(\sum x y\right)-\left(\sum x\right)\left(\sum y\right)}{n\left(\sum x^{2}\right)-\left(\sum x\right)^{2}} \\
& =\frac{3(16,767)-(3)(15,272)}{6} \\
& =0,7475
\end{aligned}
$$

Berdasarkan rumus :

$$
\begin{aligned}
a & =\frac{\sum x^{2} \cdot \sum y-\sum x \cdot \sum x y}{n\left(\sum x^{2}\right)-\left(\sum x\right)^{2}} \\
& =\frac{5 \cdot 15,272-3 \cdot 16,767}{3 \cdot 5-3^{2}} \\
& =\frac{76,36-50,301}{6} \\
& =\frac{26,059}{6} \\
& =4,343
\end{aligned}
$$

Persamaan :

$$
\begin{aligned}
& \mathrm{Y}=\underset{+}{\mathrm{a}+}+\mathrm{bx} \\
& \mathrm{Y}=4,343+0,7475 \mathrm{X} \\
& \text { Jika } \mathrm{Y}=5 \text { Maka } \\
& 5=4,343+0,7475 \mathrm{X}
\end{aligned}
$$




$$
\begin{aligned}
& 5-4,343=0,7475 \mathrm{X} \\
& 0,657=0,7475 \mathrm{X} \\
& \mathrm{X}=\frac{0,657}{0,7475} \\
& \mathrm{X}=0,8789
\end{aligned}
$$

\section{PEMBAHASAN}

Pada penelitian ini telah dilakukan Hasil penelitian uji efek antiplasmodium ekstrak etanol Rumput Teki (Cyperus rotundus L.) pada mencit jantan. Sampel diekstraksi dengan menggunakan metode maserasi.

Pengujian

efek antiplasmodium ekstrak etanol Rumput Teki merupakan uji pendahuluan untuk melihat efektifitas antiplasmodium dari Rumput Teki sebagai obat malaria dengan melihat perkembangan parasitemia pada sel darah merah terhadap hewan uji mencit jantan.

Mencit diinfeksikan dengan Plasmodium berghei, karena plasmodium jenis ini dapat menginfeksi hewan uji khususnya mencit. Plasmodium berghei merupakan jenis parasit yang umum digunakan dalam pengujian antimalaria di dalam laboratorium karena siklus hidup dan morfologinya mirip dengan Plasmodium falciparum yang menginfeksi manusia.

Mencit yang diinfeksi dengan Plasmodium berghei, dihitung jumlah parasitemia dan telah mencapai persentase parasitemia $1-5 \%$. Untuk kelompok kontrol diberikan air suling pada hari pertama sampai pada hari keempat dengan konsentrasi masingmasing $1 \mathrm{ml} / 30 \mathrm{~g}$ bobot badan. Untuk kelompok II diberi ekstrak dengan konsentrasi $2 \% \mathrm{~b} / \mathrm{v}$ pada hari pertama sampai hari keempat. Untuk kelompok III diberi ekstrak dengan konsentrasi $4 \% \mathrm{~b} / \mathrm{v}$ pada hari pertama sampai hari keempat. Untuk kelompok IV diberi ekstrak dengan konsentrasi $6 \% \mathrm{~b} / \mathrm{v}$ pada hari pertama sampai hari keempat.

Pengamatan dilakukan dengan cara membuat apusan tipis darah tepi yang diambil dengan melukai ekor mencit sebanyak 1 tetes lalu disimpan pada objek gelas, setelah kering difiksasi dengan metanol dan dibiarkan mengering kemudian ditetesi dengan larutan giemsa, didiamkan selama 10 menit dan dibilas dengan air suling. Sediaan darah apus yang telah jadi diamati pada mikroskop dengan pembesaran 100 x 10 menggunakan minyak imersi, kemudian dihitung jumlah parasitemia dengan cara menghitung jumlah eritrosit yang terinfeksi dibagi dengan jumlah eritrosit total di kali $100 \%$. Apabila telah parasit telah mencapai $1-5 \%$ maka dilakukan pengobatan dengan cara pemberian ekstrak Rumput teki selama 4 hari.

Perlakuan dilakukan selama 4 hari karena pada waktu tersebut diperkirakan telah terjadi siklus eritrositer yang berlangsung dalam sel darah merah dimana pada siklus inilah penyakit malaria meningkat.

Dari hasil penelitian diperoleh rata-rata persentase parasitemia pada mencit setelah pemberian ekstrak etanol Rumput teki $2 \%$ b/v pada hari pertama $6,56 \%$, hari kedua $15,21 \%$, hari ketiga $12,15 \%$, dan hari keempat $8,13 \%$. Untuk ekstrak etanol Rumput teki $4 \% \mathrm{~b} / \mathrm{v}$ pada hari pertama $4,89 \%$, hari kedua $10,32 \%$, hari ketiga $7,27 \%$, dan hari keempat 4,30\%. Untuk ekstrak etanol Rumput teki 6\% 
b/v pada hari pertama $4,47 \%$, hari kedua $7,93 \%$, hari ketiga 4,03\%, dan hari keempat 2,37\%. Ekstrak untuk kelompok kontrol pada hari pertama $7,587 \%$, hari kedua $17,100 \%$, hari ketiga $38,076 \%$, dan hari keempat $44,067 \%$.

Dari hasil penelitian tersebut, maka ekstrak etanol Rumput Teki terbukti dapat menurunkan persentase parasitemia dalam sel darah merah hewan uji mencit dibandingkan dengan kelompok kontrol.

\section{KESIMPULAN}

1. Ekstrak etanol Rumput Teki dengan konsentrasi $2 \%$, 4\%, dan $6 \% \mathrm{~b} / \mathrm{v}$ dapat menghambat perkembangan parasitemia dalam sel darah merah mencit jantan yang terinfeksi Plasmodium berghei.

2. Ekstrak etanol Rumput teki dengan konsentrasi $6 \% \mathrm{~b} / \mathrm{v}$ menunjukkan penurunan persentase parasitemia lebih besar yaitu 77,69 dibandingkan dengan $2 \%$ dan $4 \%$ dengan parasitemia 23,47 \% dengan $59,52 \%$.

\section{DAFTAR PUSTAKA}

Anonim, 2010, Plasmodium berghei. http://en.wikipedia,org/wiki/p lasmodium

Aswatun, 2015. Rumput teki http://www.Asiamaya.com/ja mu/isi/tekicyperusrotundus.htm

Anneahira, 2010. Pencegahan penyakit malaria http://anneahira.com/pencega han-penyakit/malaria.htm

Arlan, P., 20014.”Malaria mencegah dan mengatasinya. Puspa swara. Jakarta
Dalimartha S, 2014. Atlas Tumbuhan Obat Indonesia, jilid VI, PT. Pustaka indah, Jakarta

Ditjen POM., 2000. "Sediaan Herbal". DepKes RI. Jakarta.

Ditjen POM., 1986. "Sediaan Galenik". DepKes RI. Jakarta.

Ganiswarna., 2001. "Farmakologi dan Terapi". Bagian Farmakologi Fakultas Kedokteran UI. Jakarta.

Hariana, A., 2002. "Tumbuhan Obat \& Khasiatnya". Penebar Swadaya. Jakarta.

Heyne, K., 1987. "Tumbuhan Berbunga Indonesia II'. Badan Litbang Departemen Kehutanan. Jakarta.

Jasin, M., 2015. "Zoologi Invertebrata". Sinar Wijaya. Surabaya.

Katzung, B.G., 2014. "Farmakologi Dasar dan Klinik Penerjemah". Salemba Medika. Jakarta.

Mangan, Y., 2015. "Cara Bijak Menaklukkan Kanker”. Agro Media Pustaka. Tanggerang.

Neal, M.J., 2016. "At a Glance Farmakologi Medis", Erlangga. Jakarta.

Steenis., C.G. Van., 1987. "Flora Untuk Sekolah Di Indonesia", Terjemahan Suryowinoto. M. PT. Pradnya Paramita. Jakarta.

Sukardja., I.D.G., 2012. "Onkologi Klinik”. Airlangga University Press. Surabaya. 